\title{
A karanténok története I.
}

\author{
Felkai Péter dr.
}

\author{
Debreceni Egyetem, Általános Orvostudományi Kar, Belgyógyászati Intézet, \\ Endokrinológiai Nem Önálló Tanszék, Utazásorvostani Tanszéki Csoport, Debrecen
}

Valahányszor egy országhatáron átkelünk, fel kell mutatnunk az útlevelünket, melynek szinte minden nyelven passport a neve. Kevesen gondolkoznak el azon, hogy a szó eredeti jelentése: engedély arra, hogy a kikötőbe léphessünk. Hol is kezdődött az utazók ellenőrzése - legyen az katonai, kereskedelempolitikai vagy éppen járványügyi érdekből? $\mathrm{Az}$ első nyomokat természetesen a Bibliában találjuk meg: ahol Nehémiás, I. Artaxerxész király héber fópohárnoka olyan írást kér a perzsa uralkodótól, mely bántatlan utazást biztosít neki ősei sírjának meglátogatásához.

„És mondék a királynak: Ha tetszik a királynak, adasson nékem leveleket a folyóvizen túl lakó tiszttartókhoz, hogy hagyjanak engem utazni, mig Júdába érek (Nehémiás könyve, 2. rész, 4-9.; Károli Gáspár fordítása).

Az utazót azonban nemcsak a hatóságok zaklatása, hanem az utazással együtt járó betegségek is fenyegették. Az ókori időkből több, pusztító járványról szóló tudósítást ismerünk, és mindegyikre jellemző, hogy az emberek ösztönösen elhúzódtak a betegtől, vagy fizikálisan is kiközösítették őket a településekről. Az ókori ember korán felismerte a fertőző betegségeket, leginkább a feltûnő elváltozásokkal járó leprát. A valószínúleg az i. e. 17. században keletkezett Ószövetségben olvashatunk az elkülönítésre való utalást.

„Ha pedig fehér folt van a teste börén, de annak felülete nincs mélyebben a börnél, és a szöre sem változott meg fehérré, akkor rekessze külön a pap a fakadékos embert hét napig. A hetedik napon pedig nézze meg ót a pap, s ha szerinte a fakadék egy állapotban van, át nem terjedt tovább a fakadék a börön, a pap másodszor is rekessze ót külön hét napig. Mindaddig tisztátalan legyen, a mig rajta van a fakadék, tisztátalan az; csak ö maga lakjék, a táboron kíül legyen az ö lakása” (Mózes III. könyve 13. rész; Károli Gáspár fordítása).

Nemcsak a Biblia, de a mohamedán hagyomány is megemlékezik a járványok elleni védekezésről: „Szand mondta: A Próféta (béke és áldás kisérje) mondta, hogyba hallasz a pestis kitöréséröl valabol, ne lépj be abba a tartományba, de ha a járvány ott tör ki, abol tartózkodol, ne hagyjad el azt a helyet" (Sahih al-Bukhari, 7. kötet, 76. könyv (orvostudomány), 19. fejezet, 608. hadith [1]).

A fertőző betegségeknek azt a tulajdonságát, hogy emberről emberre képesek terjedni (tehát a betegség ragályosságát) hamar felismerték: Hippokratész (i. e. 460-370) az illóolajok bedörzsölését, illetőleg a betegtôl való távol tartást ajánlotta a fertőzés elkerülésére. Thuküdidész, Hippokratész kortársa már ennek nyomán emeli ki az athéni járvány kapcsán az emberről emberre terjedés jelenségét: „Az orvosok nem birtak vele [a járvánnyal], hiszen kezdetben a kór ismerete nélkül próbálkoztak kezelésével, s éppen közülük haltak meg a legtöbben, mivel ök érintkeztek leggyakrabban a beteggel (Thuküdidész: A peloponnészoszi háború II. 47. Ford.: Muraközi Gyula [2]).

A Justinianus császár idejében pusztító, pestisnek tartott járvány idején, i. e. 459-ben a császári rendelet előírta a járványos területekról érkezők izolálását. Lyon város tanácsának 583-ból fennmaradt rendelete megtiltja a leprás betegeknek az érintkezést az egészségesekkel. Avicenna a kb. 1020-ban keletkezett, „A gyógyászat kánonja” c. múvében leírja a „phthisis contagiosus” természetét (vagyis a légúton terjedő fertőzéseket), és karanténszerú eljárásokat javasol a terjedés megakadályozására [3]. 1170-ben a harmadik lateráni zsinat szintén a leprások elkülönítéséról rendelkezett. Az izoláció tehát a már beteg embereket különítette el az egészséges közösségtől.

A behurcolt járványok elleni védekezésnek azt a módját, hogy a lappangási idő alatt a fertőzésre gyanús személyeket nemcsak elkülönítik, de megfigyelés alatt is tartják (karantenizáció, kifejező magyar szóval vesztegzár) a nagy középkori pestisjárvány, a rettegett fekete halál hívta életre. Felismerték azt is, hogy a betegséget a betegek ruhája és tárgyai, a kereskedók árui is terjesztik. Az emberi történelem eddigi legpusztítóbb pandémiája Távol-Keletről érkezett a krími Kaffa városának falai alá, 1346-ban. A fekete halál 7 évig dühöngött a kontinensen, elpusztítva az akkori Európa lakosságának közel felét. A járvány a szicíliai Messina városából (ahol a Kaffából menekülő kereskedők kikötöttek) gyorsan terjedt Itália-szerte. A járvány sújtotta városoktól és területektől való izoláció és szeparáció volt a legkézenfekvőbb védekezés: majdnem minden város vezetôsége ilyen értelmú rendeleteket alkotott.

„abból a célból, hogy semmiféle fertôzött anyag ne juthasson a pistoiaiak testébe, elvendeljük, hogy sem a pistoiai lakosok, sem az ott tartózkodók ne merészeljenek Pisába vagy 
Luccába menni. Ugyanigy senki sem jöhet onnan Pistoiába ... 50 líra büntetés terhe alatt. És a pistoiai kapuörök állandóan vigyázzák a kapukat, és ne engedjenek be senkit onnan... Item ... Senki se merészeljen semmiféle árut, sem gyapjút, vászont vagy bármit, ami férfi- vagy nöi rubázkodásra vagy ágynemüként szolgál, behozni az emlitett városokból... Item ... A halottak testét nem szabad elmozditani addig, mig nem helyezik azt koporsóba ... a kerïlet elöljárója, hivatalnoka vagy a parókia rektora, abol a balottat találták, köteles azt bejelenteni a kerïlet podestájának. Item ... hogy elkerïljük a borzasztó szagot, a halottat 2 I/2 braccia mélyre (braccia = kar; kb. 2 méter - a szerző $)$ kell temetni, pistoiai mértékkel mérve [4].

Az itáliai városok vezetése a lakosság ilyen elkülönítését vélte kézenfekvő közegészségügyi intézkedésnek: például Milánó hercege, Bernabò Visconti 1374-ben elrendelte, hogy a himlőben szenvedók a városból kitiltassanak [5]. A rendelkezés olyan sikeres volt, hogy a himlő áldozatai egész Olaszföldön épp Milánóban voltak a legkevesebben. A beutazók egészségügyi ellenőrzése és elkülönítése később is a védekezés alapvető módszerévé vált, egészen napjainkig.

A járvány dühöngése 1350 körül elcsitult, és a tengerparti kikötővárosokban - tanulva az elmúlt keserü eseményekből - egymás után jöttek létre a karanténok. Az épületeket olyan helyen építették, melyekből nehéz volt elszökni: sokszor szigetekre telepítették az épületet, s általában a tengerpartra nézett az épület egyik szárnya, a másikat pedig magas falak és fegyveres őrség vigyázta. Hogy a karanténokban folyó ruhák kifőzésével, füvek égetésével folytatott kezelés - ha egyáltalán volt - hasz- nált-e a betegeknek, az kétséges: általában a nap és a szél „tisztító hatásában” bíztak. De a közösség szempontjából előremutató intézkedés volt, az bizonyos.

A fekete halál Dalmáciára 1348-ban csapott le. Védekezésül 1377-ben Raguza (ma: Dubrovnik) rektora, aki a velencei dózsét képviselte Dalmáciában, rendeletet hozott, hogy a kikötőbe érkező hajók személyzete 30 napig (trentine ) egy távolabbi szigeten, Mrkat szigetén, vagy a karavánút végén levő, Cavtat nevú kis településen található épületben vagy a városon kívüli karavánszerájban kötelesek tartózkodni, mielőtt a városba belépnek (1. ábra). A helyet a raguzai polgárok nem közelíthették meg, kivéve a karanténban megfigyelteket ellenőrző városi főorvost, páduai Jakabot [6]. Ez volt az első karanténrendelet a világon $[7,8]$. A harminc napot késóbb negyven napra terjesztették ki. A 40 napot a velencei (olasz) dialektusban „quaranti giorni”-nak mondják, innen származik tehát a „karantén” szavunk és az őrzött elkülönítés fogalma.

Az embert meghökkenti, hogy milyen pontosan határozták meg az elkülönítési időszakot. A három, majd később a négy hét alatt a legtöbb fertőzés már kialakul, a betegség lappangási idejét tehát a potenciálisan fertőzöttek a karanténban töltik. A lepra kivételével a középkorban pusztító nagy járványok kórokozói viszont mind tüneteket adnak a 40 napos megfigyelés alatt (1. táblázat).

A karanténnapok kiválasztása természetesen inkább megfigyelésen, mint tudományos alapokon nyugodott. Hippokratésznek a betegségterjedés megelőzését szolgáló elkülönítési időre vonatkozó ajánlásaiból vagy

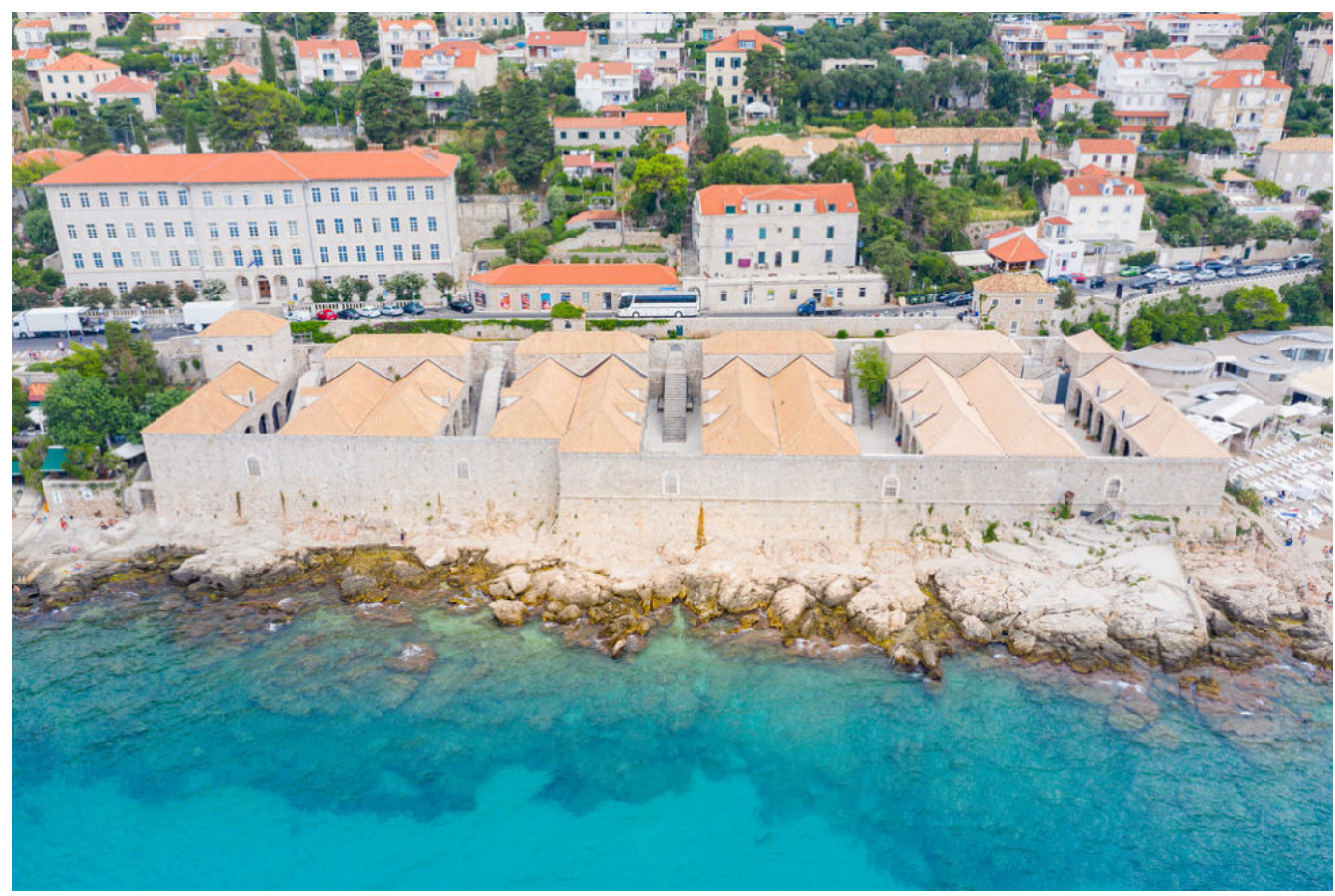

1. ábra

Az utolsó karantén a Ploce kapu közelében. A hatalmas, tíz többemeletes épületból és öt udvarból álló komplexumot, a Lazzarettit 1590 -től 1642 -ig építették. Öt épület az emberek, öt pedig az áruk elhelyezésére szolgált. Ma újjáépítve, diszkóként funkcionál (Wikipedia, public domain) 
1. táblázat | Egyes fertőző betegségek lappangási ideje

\begin{tabular}{ll}
\hline Lappangási (inkubációs) idő & A betegség néhány példája \\
\hline Rövid inkubációs idő, & Utazási hasmenések \\
kevesebb mint egy hét & Dengue-láz és más arbovírus- \\
& fertőzések \\
& Pestis \\
& COVID-19 \\
& SARS \\
\hline Közepesen hosszú inkubációs & Malária \\
idő, kevesebb mint 3 hét & Hepatitis A \\
& Rickettsiosisok \\
& Typhus \\
& Himlő (variola vera) \\
& Haemorrhagiás lázak \\
& Varicella \\
& COVID-19 \\
& Malária \\
& Leptospirosis \\
& Vírusos hepatitis (A, B, C, D, E) \\
Hosszú inkubaciós idő, & Acut HIV-fertózés \\
& Secundaer syphilis \\
& Brucellosis \\
& Acut schistosomiasis \\
& Visceralis leishmaniasis \\
&
\end{tabular}

COVID-19 = koronavírus-betegség 2019; HIV = emberi immunhiányt előidézó vírus; SARS = súlyos akut légúti tünetegyüttest okozó koronavírus-2

Pitagorasz számmisztikájából indultak ki, amelyben a 4-es az igazságot szimbolizálja, és a számok pontszerú ábrázolása négyszöget zár be. Söt még az is elképzelhető, hogy Jézus negyvennapos sivatagi böjtjére emlékezve határozták meg a karantén idejét [9], és ha már a bibliai misztikus 40 napnál tartunk: az özönvíz is ennyi ideig tartott, és a szülés után a nőknek is 40 napig tartott - a Biblia szerint - a tisztulásuk.

Velence a kor Európájának legnagyobb városa volt, lakóinak számát 120 000-150 000 fó körüli értékre tehetjük. A járvány 6 hónapos tombolása után szinte kiürült a város, naponta 600-700 ember halt meg. 1348 végére a lakosság 60\%-a veszett oda. Az Andrea Dandolo dózse vezette Signoria megpróbálta felvenni a küzdelmet a halálos kórral. Egészségügyi rendeleteket adtak ki, orvosokat fogadtak, szabályozták a város tisztítását, és kitiltották az érkező hajókat a városból [10]. Az orvosok hagyományos álarca a hosszú orral azt szolgálta, hogy megtisztítsák a fertőző levegőt, de leginkább a büz elfedésére szolgáltak (2. ábra) [11]. Az orr előtt lévő csőrben különböző füszerek parázslottak.

1423-ban a velencei Názáreti Szent Szűz szigetét (melyen már két évszázada remete szerzetesek laktak, a Názáreti Szentanyának szentelt templomuk ma is látható) a velencei Szenátus 1423. augusztus 28-i rendelete elkülönítővé alakította át. A szigeten eredetileg is egy, a szerzetesek által fenntartott menedék állt, a Szentföldre tartó és onnan visszatérő zarándokoknak. Sienai Szent Bernát tanácsára a sziget a fertőzött országokból származó áruk és személyek menedéke lett. A Lazzaretto ekkor

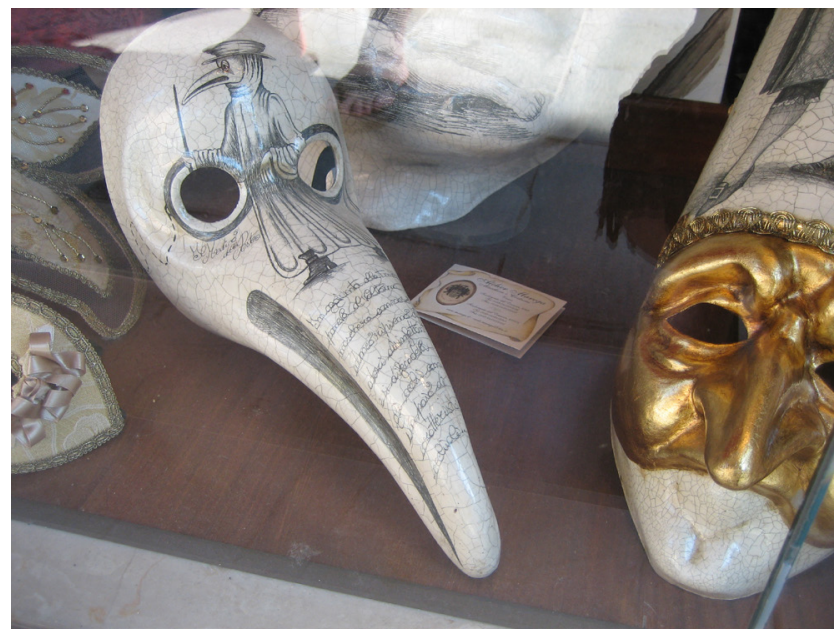

2. ábra

A járványorvosok maszkja ma is visszaköszön a velencei karnevál maszkjai között (Wikipedia Common, public domain)

már két szigetből állt, melyeket híd kötött össze: a kisebbik szigeten volt egy őrház és a szigetet őrző katonák szállása; a nagyobbikon volt maga az igazi Lazzaretto: ez magában foglalta a korábbi szerzetesi települést, eleinte fabódékkal és kunyhókkal, amelyeket fokozatosan felváltottak kőépületekkel. Szent Bernát először egy sienai konfraternitás - azaz betegápoló egyesület - tagjaként ápolta a betegeket, majd a lépcsős Szűz Mária-templom ispotályában ápolta a bubópestises betegeket. Maga is elkapta a betegséget, és majdnem belehalt.

Maga a Lazzaretto kifejezés a Nazaretto eltorzításából származik [12], de más kutatók szerint a Jézus által feltámasztott Szent Lázár adta a karanténok nevét. Mivel gyakran összetévesztik a bibliabeli leprás Lázárral, később a leprások, a sírásók és a betegek védőszentjévé választották. Jeruzsálemben 1142-ben a leprások ápolására megalapították a Szent Lázár-lovagrendet.

A velencei Szenátus 1464. április 17-én hozott rendelete szerint [13: 114. o.] minden sestiere-ből, azaz városhatodból két, nem nemes embert kellett kiválasztani, akik rendszeres jövedelmet kaptak az adóhivataltól (szó szerinti elnevezésük: Só-Hivatal volt, mivel az állami monopóliumnak számító sókereskedelemből származó adók beszedése és azokból a közmunkák és az adminisztráció finanszírozása volt a feladatuk). A két felügyelő feladata abban állt, hogy a sestiere-ben lévő minden pestisgyanús személyt a Názáretbe (Lazzaretto Vecchióra) szállíttassanak (3. ábra). E célból külön csónakok álltak rendelkezésükre. Gondoskodniuk kellett a fertőzött személy házának kiürítéséről, és az ott lakókat rá kellett beszélniük, hogy hagyják el a várost. A távozásra bírt személyt még kellő útiköltséggel is ellátták.

A szigetet ekkortól fogva hívták Lazzarettónak. Ma Lazzaretto Vecchiónak említjük, megkülönböztetésül a lagúna másik végén lévő Lazzaretto Nuovótól, melyet 1468-ban alakítottak ki karanténná, a Szenátus parancsára. A Lazzaretto Vecchio intézménye ugyanis nem volt teljesen hatásos: akiket gyógyítottak (például a pestises 


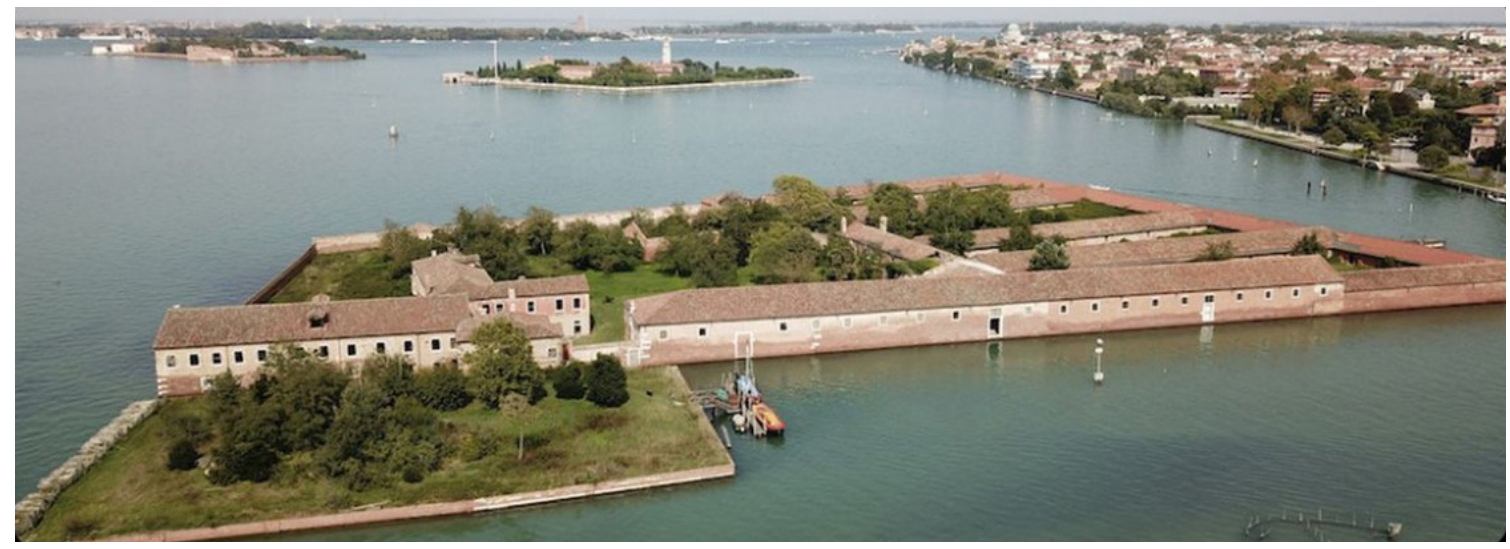

3. ábra

A Lazzaretto Vecchio ma; légi felvétel. Jobboldalt láthatók a termek, baloldalt, a kicsi szigeten lakott a fegyveres őrség (https://www.venetoworld.com/)

duzzanatok, bubók felvágásával), és látszólag meggyógyultak, még mindig magukkal vitték a fertőzést a városba (ma úgy fejeznénk ki, hogy kórokozó-ürítők maradtak), ezért a velencei egészségügyi hivatal 1541-ben a következő rendeletet adta ki [13: 115-116. o.]:

„Hogy minden lehetséges veszélyt elkerïljünk, mindazok, akik felépültek a Lazzaretto Vecchióban - tályogjaik felnyittatván meggyógyultak - a Lazzaretto Nuovo szigetére kell, hogy menjenek, de nem szabad semminemü javakat magukkal vinniük. Ott 30 napot kell eltölteniük - 15 napot a Lazzaretto „prá”-nak nevezett részében, 15 napot pedig a „sanita” nevü részében -, ezek után hazabocsáthatók, de még 10 napig nem érintkezhetnek más emberekkel. De ha valakinek olyan tályogja van, melyet nem nyitottak fel, de magától meggyógyult, annak 40 napot kell a Lazzaretto Nuovóban töltenie, 20-at a prá-ban és 20-at a sanitá-ban. Ezek után lebet csak hazaküldeni, de még 10 napig [emberekkel való érintkezési] tilalom alatt álljanak.”

Ugyanebben a rendeletben intézkedik a Szenátus a járványorvosok feladatáról: a gyanús betegek megvizsgálásáról, az elkülönítés elrendeléséről, a lehetséges megfertőződöttek személyéről (a beteget meglátogatók, orvosok, papok, a beteg barátai, idegenek - mai szóval a kontaktusok felkutatása). Az orvos a betegek gyógyításában is természetesen részt vett: a bubók felnyitása, a purgálás (érvágás) volt a mindennapos gyógymód. A megbetegedettek holmiját is karantén alá kellett venni és a szabadban szellőztetni. (A járványorvosok és a beteg borbélya is karanténba kellett, hogy kerüljenek, igaz, csak 22 napra.) A beteget, holmijával együtt a Lazzaretto Vecchióba, míg az őt ápoló személyeket és azok holmiját a Lazzaretto Nuovóba kellett szállítani.

A Lazzaretto Nuovót, az új „lábadozó” karantént a Szt. Erasmus-szigethez tartozó részen, a „Vigna Murata” (elkerített szőlőültetvény) helyén alakították ki, a Szenátus 1468. július 18-án kelt rendelete alapján [13: 115. o.]. A rendelet szerint a karantén fenntartásáért a velencei Tanács fennhatósága alá tartozó Só-Hivatal felelt, és ők fizették a hely bérét a St. Giorgo szerzeteseinek, akiknek a szőlőskert a tulajdonában volt. A Lazza- retto Vecchióból elbocsátott személyeknek itt még 40 napot kellett eltölteniük [14: 152. o.].

Toszkána a kontinens belseje felé induló kereskedelmi utak kereszteződésénél feküdt, emiatt érzékeny volt a járványok pusztítására. A nagy pestisjárvány után városaiban és tengerparti kikötőiben egymás után alakítottak ki karanténokat (Brescia: 1424; Torino: 1440; Pavia: 1449; Mantova: 1450; Genova: 1467 [15]; Siena: 1486; Firenze: 1527) [16]. Más, veszélyeztetett kikötők is a nyomukba léptek: 1476-ban Marseille-ben alakítják át a régi leprakórházat karanténná, majd miután a marseille-i kikötő forgalma tovább nőtt, a part menti Pomèguesszigeten (If várának közelében) 1521-ben alakítanak ki egy, már külön erre a célra szolgáló épületegyüttest.

A tengerparti városokban alakult ki a bajóslevelek rendszere, melyekben szerepelt a hajó indulási kikötőjének aktuális egészségügyi státusza is - így a tudottan fertőződött kikötőkből érkező hajókat nem engedték kikötni: „no pass in port”.

A velencei elkülönítőben eleinte figyelmet fordítottak a lehetőleg emberi körülményekre, hiszen a város gazdagsága a kereskedelemtől függött. Később, a zsúfoltság növekedésével már egyre elviselhetetlenebbek lettek a karanténviszonyok, mind higiénés, mind szociális szempontból. Rocco Benedetti velencei jegyző így ír erről a velencei egészségügyi hivatalnak tett jelentésében 1630ban [14: 150. o.]: „A Lazzaretto Vecchio olyan, mint maga a pokol. Mindenhonnan rettentö büz árad, melyet nem lehet leküzdeni, sóhajok és jajgatások hallatszanak szünet nélkül, és az égetett holttestek füstje árad az égnek szünet nélkül ... a balottakat az ágyukról egyenesen a sírgödörbe dobják. Gyakran megesik, hogy aki a halotthoz közel volt és eszméletlen volt, nem mozdult vagy nem jajgatott, azt is a holttesthalomba dobták. Igazán csak a szerencse müve volt, hogy ha megmozdult, vagy segitségért kiáltott, a halottszállitók emberségböl megmentették ... a pestisjárvány csúcsán nemritkán 7-8000 ember senypedett a Lazzaretto Vecchióban...”

Milánóban a pestis kitörésekor egy régi, 1448-ban a szegények számára épített kórodát szándékoztak átalakí- 


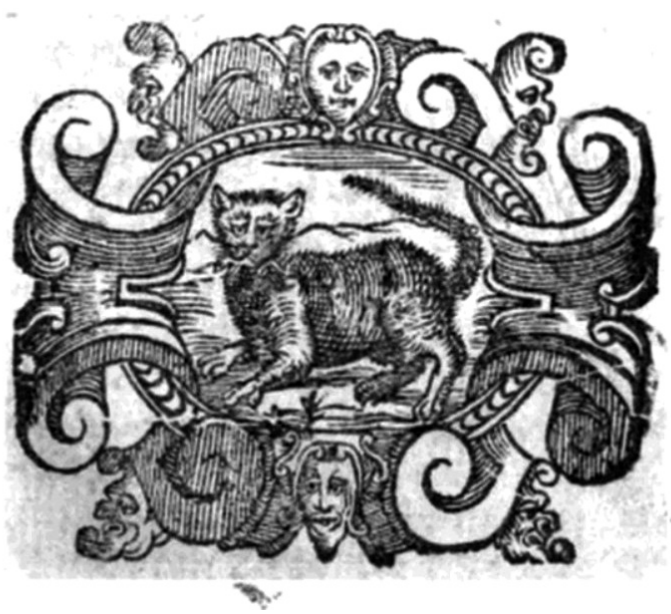

4. ábra

Alessandro Tandino „A Milánó városában és hercegségében 1629-től 1632-ig tartó nagy fertőző, mérgező és rosszindulatú pestis eredetének és elért eredményeinek ismertetése" címú könyvének címlaprészlete (a szerző másolata)

tani karanténná. Erre vonatkozóan a terveket a város jegyzője Galeazzo Maria Sforza herceg elé terjesztette: a karantén céljára egy vizesárokkal körülvett és felvonóhíddal elkülönített, 24 hektáros területet kerítettek volna el. Az épületben, középen nagy kerttel, 280 kicsi, 20 négyzetméteres szobát alakítottak volna ki. A szobáknak két ablaka (egy befele néző és egy ráccsal elválasztott a külvilág fele), két szellőzőnyílása, egy kis kandallója és egy mellékhelyisége lett volna, és az ágy szalmából készült volna, hogy a fertőtlenítéskor el lehessen égetni. Egy különálló épületben a fertőzésgyanús eseteket fogadták volna, elkülönítve őket a fertőzöttektől. Két kis templomot is terveztek, temetóvel. Az épület egyik szárnyában az orvosok, borbélyok és tisztek lakásai lettek volna [17]. Az építkezés 1488-ban kezdődött, és még 1880-ban is bővítették, amikor is a kormány eladta az épületrészeket a városnak. A lazarettet lebontották, de az egykor az épület közepén álló San Carlo al Lazzaretto templom ma is megcsodálható. A kialakított karantén a pestis 1513. és 1630. évi újbóli megjelenésekor még befejezetlenül is jó szolgálatot tett.

A karanténintézkedéseken kívül a hatóságoknak volt egy „titkos fegyverük” a pestis terjedése ellen: a házimacskák mindennél hatásosabban irtották a betegséghordozó bolhák gazdaállatait, az elszaporodott rágcsálókat. Szerepüket méltatja Alessandro Tadino olasz orvosnak az 1648-ban Milánóban megjelent könyve, melynek címlapján valószínúleg ezért egy macskát ábrázol a nyomdász (4. ábra). Tadino mint a város egészségügyi kurátora a Milánót 1629-ben újra sújtó pestis közvetlen tanúja volt, és az eseményeket történelmi pontossággal írta meg [18]. Hasonló jó szolgálatot tettek a macskák Velencében, ahol a nedves-mocsaras környezetben a rágcsálók ideális életteret találtak.

\section{Irodalom}

[1] Sahih al-Bukhari. Available from: https://sunnah.com/bukhari/ 76 [accessed: November 9, 2020].

[2] Thuküdidész. Peloponnesian War. [A peloponnészoszi háború.] Európa Könyvkiadó, Budapest, 1985. [Hungarian]

[3] Sarton G. Introduction to the History of Science. Krieger Publishing, Malabar, FL, 1975.

[4] Chiappelli A. (ed.) The sanitary regulations of the municipality of Pistoia against the pestilence of 1348. [Gli ordinamenti sanitari del Comune di Pistoia contro la pestilenza del 1348.] Archivio Storico Italiano, Vol. 20, No. 160, 1887; pp. 8-22. [Italian]

[5] Horrox R. (ed.) The black death. University Press, Manchester, 1994; p. 203.

[6] Conti AA. Quarantine through history. In: Heggenhougen HK, Quah SR. (eds.) International Encyclopedia of Public Health. Elsevier/Academic Press, Amsterdam, Boston, MA, 2008; pp. $454-462$.

[7] Frati P. Quarantine, trade and health policies in RagusaDubrovnik until the age of George Armenius-Baglivi. Med Secoli 2000; 12: 103-127.

[8] Tomic ZD. Expelling the plague: the health office and the implementation of quarantine in Dubrovnik, 1377-1533. McGillQueen's University Press, Kingston, 2015.

[9] Tognotti E. Lessons from the history of quarantine, from plague to influenza A. Emerg Infect Dis. 2013; 19: 254-259.

[10] Department of culture and fine arts. Venice and the plague 1348-1797. [Assessorato alla cultura e alle belle arti. Venezia e la peste 1348-1797.] 2nd edn. Marsilio, Venezia, 1980. [Italian]

[11] Boeckl CM. Images of plague and pestilence: iconography and iconology. Truman State University Press, Kirksville, MO, 2000; p. 27.

[12] Crawshaw JL. Plague hospitals, public health for the city in early modern Venice. Taylor \& Francis, London, New York, NY, 2016.

[13] Chambers D, Pullen B. (eds.) Venice: a documentary history 1450-1630. Blackwell, New York, NY, 1992.

[14] Byrne JP. Daily life during the black death. Greenwood Press, Westport, CT, 2006.

[15] Howard J. An account of the principal lazarettos in Europe; with various papers relative to the plague. Printed by William Eyres, Warrington (Great Britain), 1789.

[16] Bonastra Q. The forms of healthcare reform. The birth of lazare tos and renaissance hospitals. [Las formas de la reforma asistencial. El nacimiento de los lazaretos y de los hospitales renacentistas.] In: Pagés A. (dir.) Giginta. Presses Universitaires de Perpignan, 2012; pp. 197-217. [Spanish]

[17] Beltrami L. The Lazzaretto of Milan. [Il Lazzaretto di Milano.] Archivio Storico Lombardo 1881; IX(3): 403-441. [Italian]

[18] Tandino A. Information on the origin and daily successes of the great contagious, poisonous, \& maleficent plague that followed in the City of Milan, and its Duchy from the year 1629 until the year 1632. [Raguaglio dell'origine et giornali successi della gran peste contagiosa, venefica, \& malefica seguita nella Città di Milano, \& suo Ducato dall'anno 1629. fino all'anno 1632.] Ghisolfi, Milano, 1648. Available from: https://books.google.hu/ books?id=tE3yMSDpvGkC\&printsec $=$ frontcover $\& h l=h u \# v=$ on epage\&q\&f=false [accessed: November 9, 2020]. [Italian]

(Felkai Péter dr., Budapest, Szentendrei út 301., 1039 e-mail: peter.felkai@soshungary.hu)

A cikk a Creative Commons Attribution 4.0 International License (https://creativecommons.org/licenses/by/4.0/) feltételei szerint publikált Open Access közlemény, melynek szellemében a cikk bármilyen médiumban szabadon felhasználható, megosztható és újraközölhető, feltéve, hogy az eredeti szerző és a közlés helye, illetve a CC License linkje és az esetlegesen végrehajtott módosítások feltüntetésre kerülnek. (SID_1) 